Vol. 58 (2021), No. 2, 209-219

\title{
Influence of different sowing density in two varieties of maize. Part II. Relation to agricultural morphological features
}

\author{
Piotr Szulc ${ }^{1}$, Katarzyna Ambroży-Deręgowska ${ }^{2}$ \\ ${ }^{1}$ Department of Agronomy, Poznań University of Life Sciences, Dojazd 11, 60-632 Poznań, \\ Poland, e-mail: piotr.szulc@up.poznan.pl \\ ${ }^{2}$ Department of Mathematical and Statistical Methods, Poznań University of Life Sciences, \\ Wojska Polskiego 28, 60-637 Poznań, Poland, e-mail: katarzyna.ambrozy@up.poznan.pl
}

\section{SUMMARY}

In this paper, we investigate the effect of seeding density on several morphological features such as plant height, height of the production ears, ear length, ear diameter, leaf area, and LAI (leaf area index). Inference is based on a series of three-year two-factor experiments with two hybrid maize varieties - SY Cooky and Drim "stay-green" type - and 5 sowing densities: 6, 7, 8, 9 and 10 plants per $\mathrm{m}^{2}$. The "stay-green" maize variety had production cobs significantly higher on the plant, and had a thicker cob and a larger leaf assimilation area than the conventional variety. Increasing maize sowing density from 6 to 10 plants $\mathrm{m}^{-2}$ resulted in a linear decrease in cob length and diameter, while it increased the LAI. Significantly higher chlorophyll content, expressed in SPAD units, was found in the "stay-green" hybrid at the BBCH 67 stage in a wet (2012) and drier year (2014), compared with the traditional variety. This may indicate that such a variety is more tolerant to stress conditions.

Key words: chlorophyll, morphological features, sowing density, split-plot designs, Tukey's test, Zea mays L.

\section{Introduction}

The proper growth and development of maize requires appropriate agricultural practices, which should ensure the maximum productivity of photosynthesis during the period of intensive growth, contributing to obtaining high, goodquality yields (Zielewicz et al. 2021). Agricultural factors such as nitrogen fertilization (Szulc et al. 2020a), magnesium application, plant density and 
pesticides (Jagła et al. 2020) can significantly limit the normal course of photosynthesis. Nitrogen deficit in the soil also reduces crop productivity because the assimilation area is reduced. Gas exchange between the environment and the plant occurs mainly through the leaf surface. Nitrogen, as an essential component of enzymes that determines photosynthesis efficiency, shapes leaf blade growth and aging rate ( $\mathrm{Li}$ et al. 2006). The intensity of development and the long maintenance of an active assimilation surface also significantly affect the amount of effectively captured solar radiation, and hence dry matter accumulation (Muchow and Davies 1988). According to Tollenaar and Dwyer (1999), the amount of active radiation is a function of the LAI (leaf area index) value and the foliage dieback rate. Leaf area and number of leaves on the plant are important elements in evaluating photosynthesis in maize genotypes (Boote et al. 1996). Pandey et al. (2000) found that maize genotypes varied in the number of developed leaves, growth rate and biomass production under conditions of differing water and nitrogen availability. Sowing density is also likely to play a significant role in shaping the morphological features of maize plants (Greveniotis et al. 2019). Therefore, the aim of this study was to determine the effect of different sowing densities of two types of maize on (i) morphological plant features, (ii) leaf assimilation area, and (iii) chloroplast pigment contents at the BBCH 67 stage.

\section{Materials and methods}

\subsection{Experimental field}

The field experiment is described by Ambroży-Deręgowska and Szulc (2021). Briefly, the experiment was performed in the years 2012-2014 (Szulc et al. 2020b). It was carried out for three years in the same split-plot design with two factors in 4 blocks. The following factors were studied: A - first order factor: type of maize hybrid, A1 - SY Cooky, A2 - Drim, "stay-green” type; B - second order factor: sowing density, B1 - $6 \mathrm{pcs} \mathrm{m}^{-2}, \mathrm{~B} 2-7 \mathrm{pcs} \mathrm{m}^{-2}, \mathrm{~B} 3-8 \mathrm{pcs} \mathrm{m}^{-2}$, B4 -9 pcs $\mathrm{m}^{-2}$, B5 $-10 \mathrm{pcs} \mathrm{m}^{-2}$. The same level of nitrogen, phosphorus and 
potassium fertilization was applied for all experimental objects in the following

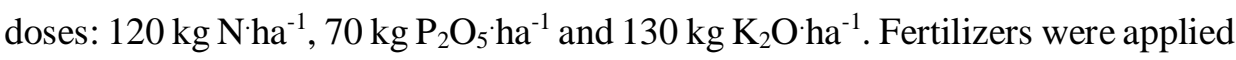
in early spring under a cultivator. Nitrogen was applied in the form of ammonia, phosphorus in triple granulated superphosphate, and potassium in the form of potassium salt.

\subsection{Weather conditions}

The thermal and humidity conditions occurring in the maize growing seasons have been described in an earlier work by the author (Szulc et al. 2020b).

\subsection{Observations and measurements}

Biometric measurements of plant height and setting of production cobs were made using a calibrated wooden bar on 20 plants in the same row. During harvesting, 10 cobs were collected from each plot and their length and diameter were measured. The methodology of determining the content of chloroplast pigments in corn leaves has been described in detail in the author's earlier work (Szulc et al. 2013). An optical device known in Europe as Hydro NTester, and in the USA as SPAD-502, was used in an indirect method of determination of maize nutritional status (Łącka et al. 2021). This apparatus works by measuring the light absorption of the leaf at two wavelengths: 650 and $940 \mathrm{~mm}$. The quotient of these differences is an indicator of chlorophyll content and is referred to as SPAD units (Soil and Plant Analysis Development). A high coefficient of determination $\left(\mathrm{R}^{2}\right)$, depending on the species, has been obtained between the instrument readings and the extracted quantity of chlorophyll (Scharf et al. 2006).

The plant assimilation area was measured during the tassel flowering period. The length and width of the fifth and sixth leaf were measured from the top of the plant on 20 consecutive plants in a row. Leaf length along the main nerve was multiplied by its width, determined at its widest point, and the result was multiplied by a factor of 0.75 . The assimilation area of the fifth and sixth leaf expressed in $\mathrm{cm}^{2}$ was determined in this manner. The leaf area of the entire plant 
was determined based on the following equation (Borowiecki et al. 1992, Szulc et al. 2013).

$$
\mathrm{LA}=-3.550+3.774 * \mathrm{X}
$$

where LA is the leaf area of the entire plant, $\mathrm{X}$ is the total area of the fifth and sixth leaf.

Having the assimilation area of one plant, it was multiplied by the number of plants per $\mathrm{m}^{2}$, thus determining the LAI (Szulc et al. 2013).

\subsection{Statistical analysis}

Statistical analyses, including analysis of variance (ANOVA) and the Tukey HSD (honestly significant difference) test for pairwise comparisons of means, were conducted separately for the years of the study and for the period 2012-2014, according to the experimental data models appropriate for experiments carried out in a split-plot design (Szulc et al. 2016). All calculations were performed using Statistica 13 (2017) and MS Excel. Statistical significance was set at p-value $<0.05$.

\section{Results}

The different weather conditions in the study years 2012-2014 were reflected in four of the considered traits: plant height $(\mathrm{cm})$, height of the production ears $(\mathrm{cm})$, ear length $(\mathrm{cm})$, and ear diameter $(\mathrm{cm})$ (Table 2$)$.

\subsection{Plant height, height of production ears, ear length, ear diameter, leaf area, LAI (leaf area index)}

The results in Table 2 indicate that, irrespective of the experimental factors (A and $B)$, significantly the lowest mean plant height $(222.21 \mathrm{~cm})$, the lowest mean height of production ears $(93.89 \mathrm{~cm})$, the lowest mean ear length $(16.13 \mathrm{~cm})$ and lowest mean ear diameter $(4.04 \mathrm{~cm})$ were obtained in 2014 . In the remaining years (2012-2013) the values of these parameters (except for mean ear length) were 
significantly higher and did not differ significantly between those two years. The highest mean ear length $(17.80 \mathrm{~cm})$ was obtained in 2013.

In this paper we discuss the relationships between factor levels on the basis of their estimates. However, when we talk about significance of factor levels, in a statistical sense, we always mean the significance of the factor levels' effects or interaction effects. Regardless of the study year and regardless of the remaining factor (B), a significant difference was noted between the means of the studied traits (except for plant height) for the two types of maize hybrid (Table 2). In the case of height of production ears $(104.50 \mathrm{~cm})$, ear diameter $(4.23 \mathrm{~cm})$, leaf area $\left(4739.80 \mathrm{~cm}^{2}\right)$ and LAI (3.73), cultivar A2 (Drim "stay-green" type) had significantly higher mean values than cultivar A1 (SY Cooky). Only the mean ear length for cultivar A1 $(17.72 \mathrm{~cm})$ was significantly higher than the mean for A2.

The results in Table 2 also indicate the significant impact of sowing densities (B), but only on the ear length, ear diameter and LAI. The highest mean ear length $(17.41 \mathrm{~cm})$ was obtained at seeding density B1 $\left(6\right.$ pcs. $\left.\mathrm{m}^{-2}\right)$; it did not differ significantly from the means for densities B2 $\left(7\right.$ pcs. $\left.\mathrm{m}^{-2}\right), \mathrm{B} 3\left(8 \mathrm{pcs} . \mathrm{m}^{-2}\right)$ and B4 $\left(9\right.$ pcs. $\left.\mathrm{m}^{-2}\right)$, but it differed significantly from the mean for density B5 (10 pcs.m $\left.{ }^{2}\right)$. Similarly, sowing density B1 $\left(6 \mathrm{pcs}^{-2} \mathrm{~m}^{-2}\right.$ produced the highest mean ear diameter $(4.18 \mathrm{~cm})$. This did not differ significantly from the means for densities B2 $\left(7\right.$ pcs. $\left.\mathrm{m}^{-2}\right)$, B3 $\left(8\right.$ pcs. $\left.\mathrm{m}^{-2}\right)$ and B4 $\left(9\right.$ pcs. $\left.\mathrm{m}^{-2}\right)$, but it differed significantly from the mean for density B5 $\left(10\right.$ pcs. $\left.\mathrm{m}^{-2}\right)$. Moreover, the highest mean LAI (4.43) was observed at seeding density B5 $\left(10\right.$ pcs. $\left.\mathrm{m}^{-2}\right)$ and the lowest mean (2.84) at seeding density B1 (6 pcs. $\left.\mathrm{m}^{-2}\right)$.

It was observed (Figures 1 and 2) that the tested types of maize hybrid (A) reacted differently to the changing conditions observed in the years covered by the study, with respect to plant height and height of production ears. For the remaining traits, no significant interactions between years $(\mathrm{Y})$ and the types of maize hybrid (A) were found. 
Table 2. Mean values of the traits for years and agrotechnical factors

\begin{tabular}{|c|c|c|c|c|c|c|c|}
\hline Factors & $\begin{array}{l}\text { Levels } \\
\text { of } \\
\text { factors }\end{array}$ & $\begin{array}{l}\text { Plant } \\
\text { height } \\
(\mathrm{cm})\end{array}$ & $\begin{array}{l}\text { Height of } \\
\text { production } \\
\text { ears }(\mathrm{cm})\end{array}$ & $\begin{array}{l}\text { Ear length } \\
(\mathrm{cm})\end{array}$ & $\begin{array}{c}\text { Ear } \\
\text { diameter } \\
(\mathrm{cm})\end{array}$ & $\begin{array}{l}\text { Leaf area } \\
\qquad\left(\mathrm{cm}^{2}\right)\end{array}$ & LAI \\
\hline \multirow{3}{*}{ Y } & 2012 & $265.90 \mathrm{a}$ & $108.03 \mathrm{a}$ & $16.95 \mathrm{~b}$ & $4.10 \mathrm{ab}$ & $4472.44 n s$ & $3.56 n s$ \\
\hline & 2013 & $258.17 \mathrm{a}$ & $103.01 \mathrm{a}$ & $17.80 \mathrm{a}$ & $4.26 \mathrm{a}$ & $4831.36 n s$ & $3.79 n s$ \\
\hline & 2014 & $222.21 \mathrm{~b}$ & $93.89 \mathrm{~b}$ & $16.13 \mathrm{c}$ & $4.04 \mathrm{~b}$ & $4558.48 n s$ & $3.58 n s$ \\
\hline \multirow{2}{*}{ A } & A1 & $247.20 n s$ & $98.79 \mathrm{~b}$ & $17.72 \mathrm{a}$ & $4.04 \mathrm{~b}$ & $4501.73 \mathrm{~b}$ & $3.56 \mathrm{~b}$ \\
\hline & $\mathrm{A} 2$ & $250.33 n s$ & $104.50 \mathrm{a}$ & $16.21 \mathrm{~b}$ & $4.23 \mathrm{a}$ & $4739.80 \mathrm{a}$ & $3.73 \mathrm{a}$ \\
\hline \multirow{5}{*}{ B } & B1 & $248.44 n s$ & $100.56 \mathrm{~ns}$ & $17.41 \mathrm{a}$ & $4.18 \mathrm{a}$ & $4722.83 n s$ & $2.84 \mathrm{e}$ \\
\hline & B2 & $250.13 n s$ & $102.25 \mathrm{~ns}$ & $17.20 \mathrm{a}$ & $4.17 \mathrm{a}$ & $4690.84 n s$ & $3.25 \mathrm{~d}$ \\
\hline & B3 & $248.10 n s$ & $101.88 \mathrm{~ns}$ & $16.89 \mathrm{ab}$ & $4.14 \mathrm{ab}$ & $4613.01 n s$ & $3.65 \mathrm{c}$ \\
\hline & B4 & $250.42 n s$ & $101.31 \mathrm{~ns}$ & $16.90 \mathrm{ab}$ & $4.11 \mathrm{ab}$ & $4569.31 \mathrm{~ns}$ & $4.05 \mathrm{~b}$ \\
\hline & B5 & $246.72 n s$ & $102.22 \mathrm{~ns}$ & $16.41 \mathrm{~b}$ & $4.06 \mathrm{~b}$ & $4507.82 \mathrm{~ns}$ & $4.43 \mathrm{a}$ \\
\hline
\end{tabular}

Values in columns with at least one letter in common do not differ significantly $(\alpha=0.05)$. $n s-$ not significant

The highest mean plant height $(272.93 \mathrm{~cm})$ was obtained for variety A2 (Drim "stay-green" type) in 2012. This mean did not differ significantly from the mean $(263.09 \mathrm{~cm})$ obtained for the same variety in 2013 , or from the mean $(258.88 \mathrm{~cm})$ obtained for variety A1 (SY Cooky) in 2012. The lowest mean plant heights were observed for both varieties in 2014 (A1: $229.46 \mathrm{~cm}$, A2: $214.96 \mathrm{~cm}$ ) (Fig. 1).

The highest mean height of the production ears $(113.12 \mathrm{~cm})$ was obtained for variety A2 (Drim "stay-green" type) in 2012. This mean did not differ significantly from the mean $(106.67 \mathrm{~cm})$ obtained for the same variety in 2013 . The lowest mean heights of production ears were obtained for both varieties in 2014 (A1: $94.06 \mathrm{~cm}$, A2: $93.72 \mathrm{~cm}$ ) (Figure 2).

The analysis of variance showed no significant interactions involving the sowing density (B). 


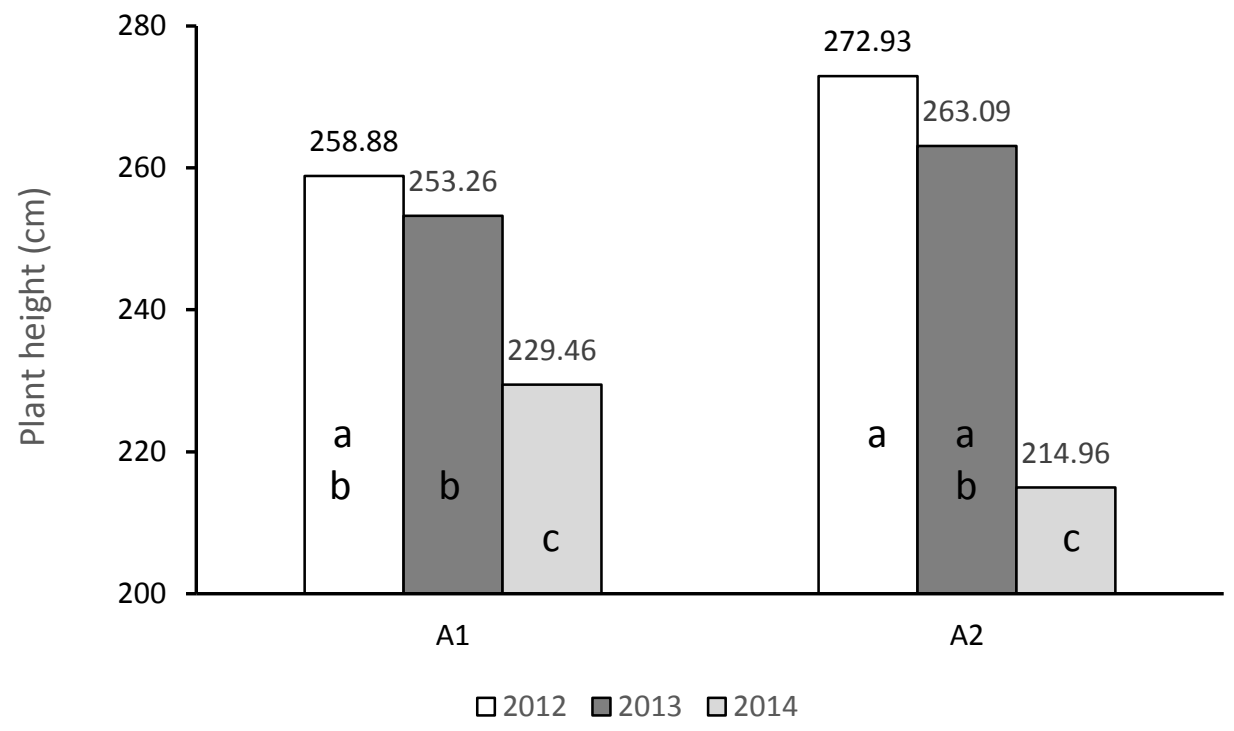

a, b, c-homogeneous groups $(\alpha=0.05)$

Figure 1. Mean values of plant height for combinations of three years and two varieties $(\mathrm{Y} \times \mathrm{A})$

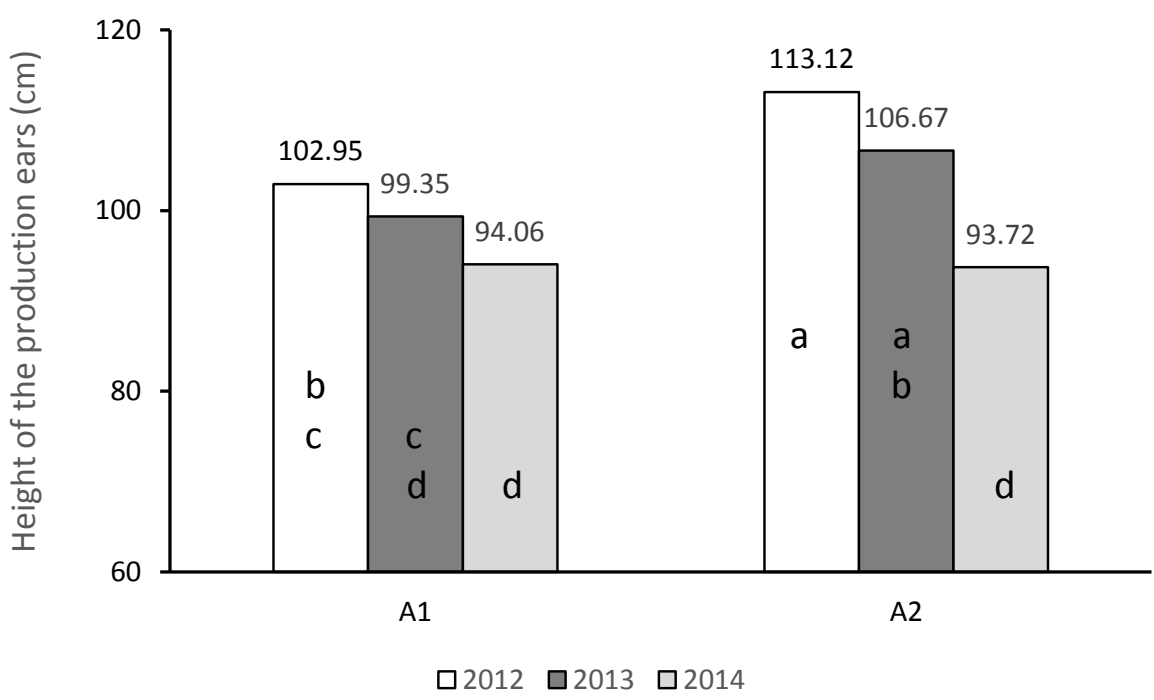

a, b, c, d-homogeneous groups $(\alpha=0.05)$

Figure 2. Mean values of height of production ears $(\mathrm{cm})$ for combinations of three years and two varieties $(\mathrm{Y} \times \mathrm{A})$ 


\subsection{Chlorophyll a, chlorophyll b, chlorophyll a+b and SPAD}

The different weather conditions over the study years 2012-2014 were not reflected in the above-mentioned traits (Table 3).

However, the tested types of maize hybrid (A) significantly influenced these traits. The highest means of chlorophyll a $\left(2.15 \mu \mathrm{gg}^{-1}\right)$, chlorophyll $\mathrm{b}$ $\left(0.638 \mu \mathrm{gg}^{-1}\right)$, chlorophyll a+b $\left(2.79 \mu \mathrm{gg}^{-1}\right)$ and SPAD (730) were obtained for cultivar A2 (Drim "stay-green” type) (Table 3).

The results in Table 3 also indicate the significant impact of sowing densities (B). The highest means of chlorophyll a $\left(2.20 \mu \mathrm{gg}^{-1}\right)$, chlorophyll b $\left(0.641 \mu \mathrm{gg}^{-1}\right)$ and chlorophyll $\mathrm{a}+\mathrm{b}\left(2.88 \mu \mathrm{gg}^{-1}\right)$ were observed at seeding density B1 $\left(6\right.$ pcs. $\left.\mathrm{m}^{-2}\right)$. These means did not differ significantly from the means for densities B2 $\left(7\right.$ pcs. $\left.\mathrm{m}^{-2}\right)$, B3 $\left(8\right.$ pcs. $\left.\mathrm{m}^{-2}\right)$ and B4 $\left(9\right.$ pcs. $\left.\mathrm{m}^{-2}\right)$, but differed significantly from the mean for density B5 $\left(10 \mathrm{pcs} \cdot \mathrm{m}^{-2}\right)$. Moreover, the highest mean SPAD (759) was obtained at seeding density B1 (6 pcs. $\left.\mathrm{m}^{-2}\right)$; it did not differ significantly from the mean for density B2 $\left(7\right.$ pcs. $\left.\mathrm{m}^{-2}\right)$. The lowest mean SPAD (684) was obtained at seeding density B5 (10 pcs. $\left.\mathrm{m}^{-2}\right)$; it did not differ significantly from the means for densities B3 $\left(8 \mathrm{pcs} . \mathrm{m}^{-2}\right)$ and B4 $\left(6 \mathrm{pcs}^{-2} \mathrm{~m}^{-2}\right.$.

Interaction between years $(\mathrm{Y})$ and cultivars $(\mathrm{A})$ was significant only for SPAD (Figure 3). The highest mean SPAD (753) was obtained for variety A2 (Drim "stay-green" type) in 2014. This mean did not differ significantly from the mean (748) obtained for the same variety in 2012, or from the means obtained for variety A1 (SY Cooky) over the study years 2012-2014.

The analysis of variance showed no significant interactions involving the sowing density (B).

\section{Conclusions}

1. Variable temperature and humidity conditions significantly affected plant height, height of production cob setting, and cob length and diameter. 
Influence of different sowing density in two varieties of maize. Part II

Table 3. Mean values of the traits for years and agrotechnical factors

\begin{tabular}{|c|c|c|c|c|c|}
\hline Factors & $\begin{array}{l}\text { Levels } \\
\text { of factors }\end{array}$ & $\begin{array}{c}\text { Chlorophyll } \\
\text { a }\left(\mu \mathrm{gg}^{-1}\right)\end{array}$ & $\begin{array}{l}\text { Chlorophyll } \\
\mathrm{b}\left(\mu \mathrm{gg}^{-1}\right)\end{array}$ & $\begin{array}{l}\text { Chlorophyll } \\
\mathrm{a}+\mathrm{b}\left(\mu \mathrm{ggg}^{-1}\right)\end{array}$ & SPAD \\
\hline \multirow{3}{*}{$Y$} & 2012 & $1.90 \mathrm{~ns}$ & $0.589 n s$ & $2.50 \mathrm{~ns}$ & $731 n s$ \\
\hline & 2013 & $1.87 n s$ & $0.550 n s$ & $2.42 n s$ & $700 n s$ \\
\hline & 2014 & $2.22 n s$ & $0.609 n s$ & $2.83 n s$ & $724 n s$ \\
\hline \multirow{2}{*}{ A } & A1 & $1.85 \mathrm{~b}$ & $0.527 \mathrm{~b}$ & $2.38 \mathrm{~b}$ & $707 \mathrm{~b}$ \\
\hline & A2 & $2.15 \mathrm{a}$ & $0.638 \mathrm{a}$ & $2.79 \mathrm{a}$ & $730 a$ \\
\hline \multirow{5}{*}{ B } & B1 & $2.20 \mathrm{a}$ & $0.641 \mathrm{a}$ & $2.88 \mathrm{a}$ & $759 a$ \\
\hline & B2 & $2.14 \mathrm{a}$ & $0.663 \mathrm{a}$ & $2.76 \mathrm{a}$ & $728 a b$ \\
\hline & B3 & $2.04 \mathrm{ab}$ & $0.584 \mathrm{ab}$ & $2.63 \mathrm{ab}$ & $707 \mathrm{bc}$ \\
\hline & B4 & $1.90 \mathrm{ab}$ & $0.541 \mathrm{ab}$ & $2.45 \mathrm{ab}$ & $715 \mathrm{bc}$ \\
\hline & B5 & $1.72 \mathrm{~b}$ & $0.486 \mathrm{~b}$ & $2.21 \mathrm{~b}$ & $684 \mathrm{c}$ \\
\hline
\end{tabular}

Values in columns with at least one letter in common do not differ significantly. $n s-$ not significant

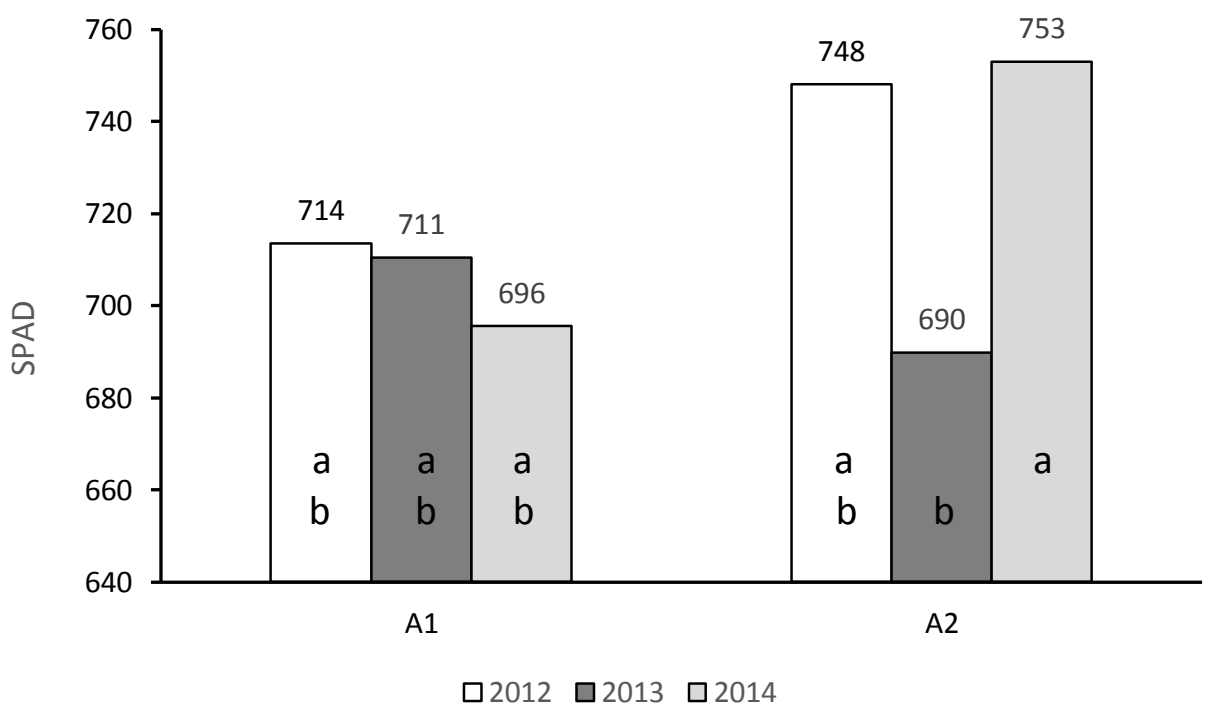

$\mathrm{a}, \mathrm{b}$ - homogeneous groups

Figure 3. Mean values of SPAD for combinations of three years and two varieties $(\mathrm{Y} \times \mathrm{A})$ 
2. The "stay-green" maize variety had production cobs significantly higher on the plant and had a thicker cob and a larger leaf assimilation area than the conventional variety.

3. Increasing the maize sowing density from 6 to 10 plants $\mathrm{m}^{-2}$ resulted in a linear decrease in cob length and diameter, while increasing the LAI.

4. Significantly higher chloroplast pigment contents were recorded in the "staygreen" maize hybrid than in the classical variety.

5. Chloroplast pigment contents in the leaves decreased with an increase in plant density in the maize field.

6. A significantly higher chlorophyll content, expressed in SPAD units, was found for the "stay-green" hybrid at the BBCH 67 stage in a wet (2012) and drier year (2014), compared with the traditional variety. This may indicate that such a variety is more tolerant to stress conditions.

\section{REFERENCES}

Ambroży-Deręgowska K., Szulc P. (2021): Influence of different sowing density in two varieties of maize. Part I. Relation to yielding. Biometrical Letters 58(2): 199-208.

Boote K.B., Jones J.W., Pickering N.B. (1996): Potential uses and limitations of crop models. Agronomy Journal 88: 704-716.

Borowiecki J., Filipiak K. (1992): Wybór liści wskaźnikowych do określenia powierzchni liściowej kukurydzy. Pamiętnik Puławski, Zeszyt 100: 77-85.

Greveniotis V., Zotis S., Sioki E., Ipsilandis C. (2019); Field population density effects on field yield and morphological characteristics of maize. Agriculture 9: 160.

Jagła M., Sobiech Ł., Szulc P., Nowosad K., Bocianowski J., Grzanka M. (2020): Sensitivity assessment of varieties, effectiveness of weed control by selected herbicides in maize (Zea mays L.) cultivation. Agronomy 10: 1115.

Łącka A., Nowosad K., Bocianowski J., Szulc P. (2021): Heredity of chloroplast pigments parameters of maize (Zea mays L.). Maydica 66, M5.

Li F.Y., Jamieson P.D., Pearson A.J. (2006): Amaize N: Developing a decision-support tool to optimize nitrogen management of maize. Proceedings of the Agronomy Society of New Zealand 36: 61-70.

Muchow R.C., Davies R. (1988): Effect of nitrogen supply on the comparative productivity of maize and sorghum in a semi-arid tropical environment II. Radiation interception and biomass accumulation. Field Crops Research 18: 17-30.

Pandey R.K., Maranville J.W., Chetima M.M. (2000): Deficit irrigation and nitrogen effects on maize in a Sahelian environment. II. Shoot growth, nitrogen uptake and water extraction. Agriculture and Water Management 46: 15-27. 
Scharf P.C., Brouder M.S., Hoeft G.R. (2006): Chlorophyll meter readings can predict nitrogen need and yield response of corn in the North-Central USA. Agronomy Journal 98: 655-665.

Szulc P., Ambroży-Deręgowska K., Mejza I., Kobus-Cisowska J., Ligaj M. (2020a): The role of agrotechnical factors in shaping protein yield of maize (Zea mays L.). Sustainability 12: 6833.

Szulc P., Bocianowski J., Rybus-Zając M. (2013): Influence of soil supplementation with nitrogen and magnesium on the size of assimilation area of maize cultivars (Zea mays L.) differing in genetic profile. EJPAU, 16(2) \#01.

Szulc P., Mejza, I., Ambroży-Deręgowska, K., Nowosad, K., Bocianowski, J. (2016): The comparison of three models applied to the analysis of three-factor trial on hybrid maize (Zea mays L.) cultivars. Biometrical Letters 53(1): 47-57.

Szulc P., Ambroży-Deręgowska K., Mejza I., Zawadzka A., Zielewicz W., Byczkiewicz S. (2020b): The reaction of two types of maize cultivars (Zea mays L.) to different sowing density. Journal of Research and Applications in Agricultural Engineering 65 (2): $12-17$

Tollenaar M., Dwyer L.M. (1999): Physiology of maize, pp. 169-204. In: Crop yield: Physiology and processes. Eds. Smith, D.L.; Hamel, C. Springer-Verlag Berlin Heidelberg, New York.

Zielewicz W., Wróbel B., Szulc P., Bujak H., Stachowiak B. (2021): By-plant prediction of dry matter yields at various growth stages of maize plants (Zea mays L.) using leaf greenness indicator in climatic conditions of Poland. Applied Sciences 11: 9513. 